\title{
DIVIDEND POLICY AND SHARE PRICE VOLATILITY: EVIDENCE FROM LISTED NON-FINANCIAL FIRMS IN SRI LANKA
}

\author{
Lingesiya Kengatharan* \\ University of Jaffna \\ Jeyan Suganya Dimon Ford \\ University of Jaffna
}

\begin{abstract}
The prime objective of this research is to investigate the impact of dividend policy on share price volatility in Colombo Stock Exchange (CSE). A sample of 81 listed non -financial firms from CSE in Sri Lanka is examined using panel data analysis for a five years period from 2013 to 2017. Dividend policy of the firms has been measured by dividend pay-out, dividend yield and dividend per share and which are explanatory variables of the study after controlling for firm size and financial leverage. According to the random effect regression analysis, only $25 \%$ of the movements in share prices are explained by the explanatory variables considered in this study. Dividend yield shows significant positive impact on share price volatility whereas dividend per share shows the significant negative impact on share price movements. Firm size illustrates significant negative influence on share price volatility by indicating large size of companies share price volatility is high. But, dividend pay-out and financial leverage are not significantly persuaded on share price volatility in this study. Therefore, it is concluded that dividend yield, dividend per share and firm size have significant impact on price volatility in Sri Lankan context and findings of the study are in line with the dividend relevance theory. Dividend policy can be considered as the protective mechanism to maintain share price volatility in order to enhance the shareholders wealth.
\end{abstract}

Keywords: Dividend Payout, Dividend Yield, Dividend Per Share, Share Price Volatility.

Received: 24 October 2019

Accepted: 31 December 2020

https://doi.org/10.33736/ijbs.3172.2021

\section{INTRODUCTION}

Primary aim of profitable organisations which is maximization of shareholders' wealth does not rely on only one particular decision. It will be accomplished with four types of most important financial decisions such as investment decision, financing decision, dividend decision and working capital management decision. This study mainly focuses on dividend decision as it is considered as major factor to examine share price volatility of a company. Shareholders' wealth directly relates to value of the firm measured using market price of share. Share price movement will either be bullish (up) or be bearish (down) trend this is called volatility of share price. Even

\footnotetext{
- Corresponding Author: Department of Financial Management, University of Jaffna, Sri Lanka; Tel: +94764014277; Email: lingesiya@univ.jfn.ac.lk
} 
though it would be determined by many factors, foremost, share price is depending on demand and supply of a particular share in the market. It mainly relies on percentage of dividend provided by a particular firm as investors invest their money in shares of a firm with the expectation of getting higher return on their investment. Firms usually keep part of their earning as retained earnings for various purposes and rest of the earnings will be provided as dividend to the shareholders. Therefore, investors will prefer shares of the firm which is providing dividend at higher percentage to earn more. Since higher risk is associated with higher return, investors who are expecting higher return should be ready to bear higher risk. Risk in the stock market is measured by volatility of share price since it involves in changing price movement of shares (Mgbame \& Ikhatua, 2013).

A policy which is used by the company to determine its dividend payout to shareholders is called as dividend policy. Dividend Policy indicates the percentage flow of remaining net income to shareholders (Fama \& French, 1988). As per the previous studies (Baker and Powell,1999; Hussainey, Mgbame, \& Chijoke-Mgbame, 2011; Gulet, Sajid, Razzaq, Iqbal, \& Khan, 2012; Zainudin, Mahdzan, \& Yet, 2018) dividend policy has direct impact on share price volatility as well as firm value. Different theories were developed to show the link between divided policy and share price movement in the past. It was examined in many countries in various years. However, unresolved problem on the theories compared with practical are still discussed by many researchers as previous findings revealed contradictory results. Most of the researchers have just used correlation and multiple regression analysis to examine the research problem rather considering panel data analysis even though data that was derived from different companies for multiple time period. Therefore, this study intends to examine impact of dividend policy on share price volatility among non-financial institutions listed in Colombo Stock Exchange, Sri Lanka using panel data analysis as it may have time and industry effect on the data. Sri Lankan stock market has been found as frontier market, since it is located in developing country that is less advanced than emerging market like China and India. When the people have awareness of price movement of shares and its determinants, they will be attracted to invest in share market in Sri Lanka. It may lead to develop capital market in countries like Sri Lanka. In order to make the decision based on the share price volatility in terms of dividend policy, very limited recent studies were found in Sri Lanka (Harshapriya, 2016; Gunarathne, Priyadarshanie, \& Samarakoon, 2016; Dewasiri \& Weerakoon Banda, 2014). Therefore, this study will give an idea not only to investors for making their investment decision but also to management of the company to formulate dividend policies according to the behaviour of investors in Sri Lanka at present.

\section{LITERATURE REVIEW}

It consists of theoretical framework which explains the theories behind this study and empirical review reveals the similar studies carried out in various countries by different researchers.

\subsection{Theoretical Framework}

Numerous theories were developed by scholars time to time to show how dividend acts to move share price in the market. This study is carried out under the three main theories in regard to the relationship between dividend policy and stock price volatility. 
Miller and Modigliani (1961) developed the first theory called dividend irrelevant theory says that investment and financing decision are used to determine value of the firm as well as share price and it is not determined by dividend decision with some assumptions under perfect market situation. Black and Scholes (1974) acknowledge the above argument with the finding of their study using capital assets pricing model. Soon after MM theory, Farrar and Selwyn (1967) argued against irrelevancy theory of dividend regarding taxation on capital structure. They said that higher tax rate on personal income such as dividend than capital gain may lead to lower the value of share. Brennan (1970) and Litzenberger and Ramaswamy (1979) arrived at same conclusion with Farrar and Selwyn (1967).

Another theory developed by Gordon (1963) and Lintner (1962) as a response to dividend irrelevancy theory developed by Modigliani and Miller's in 1961. They insist that dividend affect the stock's price and investors' behaviour. Because, it was found that they prefer cash dividends over capital gain as future profits from capital gain are uncertain and there is information asymmetry. When dividend is provided at high rate it will allow shareholders to increase their wealth through influencing its stock price. The concept was supported by other researchers (Ball, Brown, Finn, \& Officer, 1979; Woolridge, 1983) with their findings of the studies. Besides these theories, signalling theory was also developed to discuss about how firm value is influenced by dividend policy of the firm. Asquith and David (1983) stated that when management declares dividends, it conveys a strong signal that the company has enough cash to provide dividend. Therefore, if investors purchase shares of the firm they may benefited with expected return in future.

\subsection{Empirical Review}

\subsubsection{Share Price Volatility}

Unpredictable change in share price is called as share price volatility. Higher risk in the stock market can be identified when there is a high share price volatility and vice versa. It is considered as a dependent variable in this study. It is measured in different method using various formulas. But the formula used in this study to calculate share price volatility is similar to measurement used by most of the previous researchers (Nazir, Abdullah \& Nawaz, 2012; Hussainey et al., 2011; Zakaria, Muhammad \& Zulkifli, 2012; Harshapriya, 2016) considering risk.

$$
\begin{aligned}
& \text { Share Price Volatility }=\sqrt{\frac{(\text { MPSh }- \text { MPS } l)}{\left(\frac{M P S+M P S l}{2}\right)^{2}}} \\
& \text { MPS } h=\text { Highest market price per share } \\
& \text { MPS } l=\text { Lowest market price per share }
\end{aligned}
$$

\subsubsection{Dividend Payout}

The percentage of earnings paid out to shareholders as dividend is meant dividend payout. It helps investors to make sure a company can be maintained payment of divided continuously in 
the long run. Sugathadasa (2018) stated that there is an insignificant relationship between dividend payout and share price volatility from the study done in Sri Lankan Colombo stock exchange. Nevertheless, Harshapriya (2016) found significant negative relationship between dividend payout and stock price volatility in her study carried out in Sri Lanka. Hussainey et al., (2011) in UK stock market, Nguyen, Bui and Do, (2019) in Vietnam, AlQudah and Yusuf (2015) in Jordanian firms, Hashemijoo, Ardekani, and Younesi (2012) and Hooi, Albaity, and Ibrahimy (2015) in Malaysian firms found that dividend payout ratio has significant negative relationship with share price volatility. However, Mehmood (2019) carried out a study in Pakistan revealed significant positive impact of dividend payout ratio on share price volatility. Most of the literatures regarding dividend payout ratio was found to be a significant negative relationship between payout and share price volatility. Dividend payout is calculated by dividing dividend per share of a firm by earnings per share of particular firm.

$$
\text { Dividend payout }=\frac{\text { Dividend per share }}{\text { Earnings per share }}
$$

Current study hypothesized as:

$H_{1}$ : There is a significant impact of dividend payout on stock price volatility.

\subsubsection{Dividend Yield}

Dividend yield tells that how much income will be received relation to share price. Fama and French (1988) say that dividend can predict stock returns. Shah and Noreen (2016) found significant negative relationship between dividend and share price volatility among Pakistan firms. Ahmad, Alrjoub and Alrabba (2018) carried out a study to examine the effect of dividend policy on stock price volatility in Jordan. It was found that there is a significant negative relationship between dividend yield and movement of stock price. It means that higher dividend yield of the firms makes the stock price volatility lower which lead to more stability of the stock price. However, Al-Shawawreh (2014) found that there is a very weak positive relationship between dividend yield and share price volatility in his study done in Jordan. Gunarathne et al., (2016) have found that previous year dividend yield has significant and positive impact on share price volatility while current year dividend yield doesn't have any impact on share price volatility among manufacturing firms in Sri Lanka. Dividend yield is calculated by dividing annual dividend per share by average market price per share. Similar formula was used by Zakaria et al., (2012) and Harshapriya (2016) for calculating dividend yield.

$$
\text { Dividend Yield }=\frac{\text { Dividend per share }}{\text { Average Market Price per Share }}
$$

$\mathrm{H}_{2}$ : There is a significant impact of dividend yield on stock price volatility.

\subsubsection{Dividend per Share}

Dividend per share is the total amount of dividend declared for each ordinary share outstanding. Investors who expect stable income for their investment use this ratio to determine how much money is distributed by the firm to their shareholders. Dissanayake and Wickramasinghe (2016) 
found that there is no any significant impact of dividend per share on share price volatility among Sri Lankan firms. Sulaiman (2015) revealed the result of similar study in Nigeria that the dividend per share indicated significant positive connection with stock price changes. Most of the researchers who have intended to examine impact of dividend policy on share price volatility didn't take dividend per share as an explanatory variable. Dividend per share will be calculated by total dividend by shares outstanding.

$$
\text { Dividend per share }=\frac{\text { Total dividend paid }}{\text { Numberof ondinary shares outstanding }}
$$

$H_{3}:$ There is a significant impact of dividend per share on stock price volatility.

\subsubsection{Firm Size}

Firm size is considered as controlling variable of the study used the same in the previous studies (Zakaria et al., 2012; Lashgari \& Ahmadi, 2014). It can be measured in different ways for various purposes such as number of employees, total assets and total sales revenue. In this study it is measured using total sales revenue as sample consist of service organisations which do not have valuable tangible assets compared to other types of firms. Previous studies show various relationship between firm size and share price volatility. Al-Shawawreh (2014) in Jordan, Ahmad et al., (2018) in Jordan, Zakaria et al., (2012) in Malaysia, Dewasiri and Weerakoon Banda (2015) Sri Lanka and Nuwani (2015) in Sri Lanka found significant positive relationship between firm size and share price volatility while Hashemijoo et al., (2012) in Malaysia, Shah and Noreen (2016) in Pakistan, Ali and Waheed (2017) in Pakistan and Hooi et al., (2015) in Malaysia found significant negative relationship between them. It is calculated using natural logarithm of total sales.

$$
\text { Firm size }=\log (\text { total sales })
$$

$\mathrm{H}_{4}$ : There is a significant impact of firm size on stock price volatility.

\subsubsection{Leverage}

Leverage is also used as a control variable of the study as used in previous studies. It is a borrowed capital in the firm used as a funding source for financing assets of the firm. When the leverage is beyond the limit, it may be risk for the firm there by volatility of equity price may increase. Positive significant impact of leverage on share price volatility was found in studies done by Ahmad et al., (2018) in Jordan and Ali and Waheed (2017) in Pakistan. But, Shah and Noreen (2016) in Pakistan and Zakaria et al., (2012) in Malaysia found significant negative relationship between leverage and share price volatility. It is calculated in various ways, but in this study it is calculated by dividing total debt by total assets.

$$
\text { Leverage }=\frac{\text { Total debt }}{\text { Total assets }}
$$

$H_{5}$ : There is a significant impact of leverage on stock price volatility. 


\section{RESEARCH METHODOLOGY}

\subsection{Sampling and Data Collection}

The major aim of the study is to examine the impact of dividend policy on share price volatility of non financial firms listed in Colombo stock exchange, Sri Lanka. Sample of the study is 81 non-financial firms selected under random sampling method from Population of 225 nonfinancial firms. Some firm in the population were eliminated purposively as they don't have enough relevant data, few of them didn't issue dividend for all five years from 2013 to 2017 and unavailability of annual reports since they have listed in the Colombo Stock Exchange only before three years. The secondary data for this study was retrieved from the annual report of sample firms for the period of five years from 2013 to 2017.

\subsection{Research Model}

Aim of the study is to investigate the impact of dividend policy on share price volatility focusing Sri Lankan listed non financial firms in Sri Lanka. Panel data takes into account the observations regarding comparable transversal units over a large number of time periods; there may be crosssectional effects on each company or on a group of companies. Numerous methods are available to solve these types of problems, although the models with fixed and random effects in panel econometric techniques are more essential. The fixed effects model takes into account the independence of each company or cross-sectional unit included in the sample by allowing interception to vary per company, but still assumes that the slope coefficients within the companies are constant (Pratheepan \& Yatiwella, 2016).

The random effects model estimates the coefficients based on the assumption that the individual or group effects are not correlated with other independent variables and can be formulated (Pratheepan \& Yatiwella, 2016). For purpose of selecting method of analysis that is most suitable to conduct the empirical analysis, pooled OLS, fixed and random effect models are performed.

Pooled OLS model

$S P V_{\text {it }}=\alpha_{0}+\alpha_{1} D P_{\text {it }}+\alpha_{2} D Y_{\text {it }}+\alpha_{3} D P S_{\text {it }}+\alpha_{4} L E V_{i t}+\alpha_{5} F S_{i t}+\varepsilon_{i t}$

Fixed Effect Model

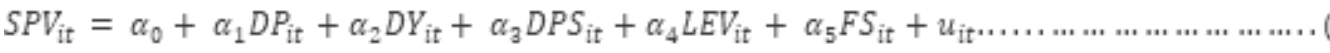

Random Effect Model

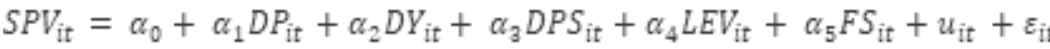

In the equation:

$\mathrm{SPV}_{\mathrm{it}}$ is share price volatility of firm $i$ at time $t$.

$\mathrm{DP}_{\mathrm{it}}$ is dividend payout of firm $\mathrm{i}$ at time $\mathrm{t}$.

$\mathrm{DY}_{\mathrm{it}}$ is dividend yield of firm $\mathrm{i}$ at time $\mathrm{t}$.

$\mathrm{DPS}_{\mathrm{it}}$ is the dividend per share of firm $\mathrm{i}$ in time $\mathrm{t}$.

$\mathrm{LEV}_{\mathrm{it}}$ is financial leverage of a firm $i$ at time $t$.

$\mathrm{FS}_{\mathrm{it}}$ is Size of firm i at time t. 
$\alpha_{0}$ - intercept coefficient of firm i at time t.

$\alpha_{1}, \alpha_{2}, \alpha_{3}, \alpha_{4}, \& \alpha_{5}$ - row vectors of slope coefficient of regressors

$\varepsilon_{\mathrm{it}}$ : Stochastic error term of firm $\mathrm{i}$ at time $\mathrm{t}$

$\mathrm{u}_{\mathrm{it}}$ : error term of firm $\mathrm{i}$ at time $\mathrm{t}$

\section{RESULTS AND DISCUSSIONS}

\subsection{Descriptive Statistics}

It shows summary of collected data from each company over time period for this study. It enables to provide basic information about variables in a dataset.

Table 1: Descriptive Statistics

\begin{tabular}{cccccc}
\hline \hline Variables & Obs & Mean & St.Dev. & Minimum & Maximum \\
\hline Dividend Payout & 405 & .5068 & 1.0402 & -7.6272 & 11.3557 \\
Dividend Yield & 405 & .0396 & .0393 & 0 & .4735 \\
Dividend Per Share & 405 & 6.3765 & 13.3900 & 0 & 85 \\
Leverage & 405 & .3605 & .2178 & .0099 & .9702 \\
Firm Size & 405 & 9.7958 & .4482 & 8.7355 & 11.1544 \\
Share Price Volatility & 405 & .1047 & .0842 & 0 & .4665 \\
\hline \hline
\end{tabular}

As per the descriptive statistics presented in the table 1, mean value of dividend payout is .5068 . It has the range from -7.6272 to 11.3557 . Dividend yield ranges from 0 to 0.4735 and mean value is 0.0396 with the standard deviation of .0393 . Dividend per share has mean value of 6.3765 with the minimum value is 0 and maximum value is 85. Leverage ranges from .0099 to .9702 and mean value is .3605 with the standard deviation of .2178. Firm size has the mean value 9.7958. Mean value of the share price volatility is 0.1047 which ranges from 0 to .4665 . This is the general information of the data collected for this study.

\subsection{Correlation Analysis}

It is performed to measure strength of relationship only between a pair of variables. It does not allow to think about cause and effect. It leads to quantify how well two variables relate to each other. Therefore, it is treated as a basic analysis to move further advanced statistical analysis. 
Table 2: Correlation Analysis

\begin{tabular}{|c|c|c|c|c|c|c|}
\hline & DPR & DY & DPS & LEV & FS & SPV \\
\hline DPR & 1.0000 & & & & & \\
\hline DY & $\begin{array}{c}0.4480^{*} \\
0.0000\end{array}$ & 1.0000 & & & & \\
\hline DPS & $\begin{array}{c}0.1597 * \\
0.0013\end{array}$ & $\begin{array}{c}0.1929 * \\
0.0001\end{array}$ & 1.0000 & & & \\
\hline LEV & $\begin{array}{c}-0.0122 \\
0.8067\end{array}$ & $\begin{array}{l}0.0229 \\
0.6460\end{array}$ & $\begin{array}{l}0.1222 \\
0.0138\end{array}$ & 1.0000 & & \\
\hline FS & $\begin{array}{l}0.0046 \\
0.9267\end{array}$ & $\begin{array}{c}-0.0329 \\
0.5090\end{array}$ & $\begin{array}{l}0.0192 \\
0.6955\end{array}$ & $\begin{array}{c}0.1770 * \\
0.0003\end{array}$ & 1.0000 & \\
\hline SPV & $\begin{array}{c}-0.0834 \\
0.0939\end{array}$ & $\begin{array}{c}0.1301 * \\
0.0088\end{array}$ & $\begin{array}{c}-0.3824 * \\
0.0000\end{array}$ & $\begin{array}{c}0.1129 * \\
0.0231\end{array}$ & $\begin{array}{c}-0.1775 * \\
0.0003\end{array}$ & 1.0000 \\
\hline
\end{tabular}

* correlation is significant at the 0.05 level ( 2 tailed)

Result of correlation analysis between explanatory variables and dependent variable is presented in table 2. According to this results, dividend payout ratio is not significantly associated with share price volatility $(\mathrm{r}=-0.0834, \mathrm{P}=0.0939)$. But all other explanatory variables considered in this study which are dividend yield $(\mathrm{r}=0.1301, \mathrm{P}=0.0088)$, dividend per share $(\mathrm{r}=-0.3824, \mathrm{P}=$ $0.0000)$, leverage $(\mathrm{r}=0.0029, \mathrm{P}=0.0231)$ and firm size $(\mathrm{r}=-0.1775, \mathrm{P}=0.0003)$ are significantly correlated with share price volatility. Therefore, it can be concluded that dividend yield and leverage have positive association with share price movements while dividend per share and firm size have significant negative association with share price volatility.

\subsection{Test for Variance Inflation Factor (VIF)}

Variance Inflation Factor (VIF) and Tolerance can be used to analyse the multicollinearity among the independent variables. The VIF measures the extent the variance of estimated regression coefficients are inflated as a result of being related to the other independent variables, and Tolerance is the amount of variability of the selected independent variables not explained by other independent variables (Al-Shawawreh, 2014). Any variables with a VIF value above 10 or with a value below 0.10 of Tolerance would have a correlation of more than 0.90 with other variables, indicative of the Multi-co linearity problem (Hair,Tatham \& Anderson, 1998). Results of VIF test of this study presented in the table 3 explain that there is no multicollinearity among the explanatory variables.

Table 3: Values of Variance Inflation Factor

\begin{tabular}{ccc}
\hline \hline Variable & VIF & $\mathbf{1 / V I F}$ \\
\hline DPR & 1.28 & 0.7823 \\
DY & 1.26 & 0.7921 \\
DPS & 1.06 & 0.9416 \\
LEV & 1.05 & 0.9530 \\
FS & 1.03 & 0.9666 \\
\hline Mean VIF & 1.14 & \\
\hline \hline
\end{tabular}




\subsection{Panel Data Regression Analysis}

Since the data used in this study collected from various firms for different year period, panel data regression analysis is employed to test hypotheses. Because it can resolve the problem with entity effect and time effect in the data set. Therefore, Breusch and Pagan Lagrangian Multiplier Test and Hausman Specification Test were employed to find which of Pooled OLS, fixed effect and random effect model is appropriate to explain finding of the study.

Table 4: Panel Data Regression Analysis

\begin{tabular}{lccc}
\hline \hline \multicolumn{1}{c}{ Variable } & Pooled OLS & Fixed effect & Random effect \\
\hline C & (Coef) & (Coef) & (Coef) \\
Dividend Payout & $0.4353^{* *}$ & 0.9398 & $0.5669^{* *}$ \\
Dividend Yield & $-0.0103^{* *}$ & -0.0026 & -0.0032 \\
Dividend Per Share & $0.5551^{* *}$ & $0.3772^{* *}$ & $0.4406^{* *}$ \\
Leverage & $-0.0027^{* *}$ & $-0.0008^{*}$ & $-0.0016^{* *}$ \\
Firm Size & $0.0743^{* *}$ & 0.0355 & 0.0441 \\
No. of obs & $-0.3643^{* *}$ & $-0.0873 *$ & $-0.0494 *$ \\
R-square & 405 & 405 & 405 \\
F-statistic/ Wald Chi ${ }^{2}$ of the & 0.2657 & 0.1211 & 0.2517 \\
model and P Value & & & $55.28(0.000)$ \\
F Test & $28.87(0.000)$ & $6.91(0.000)$ & \\
(Pooled VS Fixed) & & & \\
Breush \& Pegan Lagrange & & $15.92(0.000)$ & \\
Multiplier Test & & & \\
(Pooled VS Random) & & & \\
Hausman Specification Test & & & \\
(Fixed Vs Random) & & $4.73(0.4494)$ & \\
*/** indicate coefficient is statistically significant at the 5/1 percent level of significance respectively.
\end{tabular}

Table 4 illustrates the results of pooled OLS, fixed effect and random effect models to investigate the impact of divided policy on share price volatility in Sri Lankan non financial firms for the 5 years period from 2013 to 2017 . As per their probability values of the F statistics indicated in the Table 4, all three models are significant to explain the impact of dividend policy on share price volatility (pooled OLS model: $\mathrm{F}=28.87, \mathrm{P}=0.000$; fixed effect model: $\mathrm{F}=6.91, \mathrm{P}=0.000$; and random effect model: $\mathrm{F}=55.28, \mathrm{P}=0.000$ ). Even though, it is identified that which model is more suitable to explain the impact of dividend policy on the share price volatility by performing the relevant analysis.

Firstly, F test is performed to compare the pooled OLS model and fixed effect model and it is hypothesised that null hypothesis $=$ fixed effect does not exist, alternative $=$ fixed effect exist. As per the results summarised in the table 4, outcome of the F test revealed that $\mathrm{p}$ value is less than 0.01 and therefore null hypothesis is rejected that there are time fixed effects in the model. Secondly, Breusch and Pagan Lagrangian Multiplier test is performed to compare the pooled OLS model and random effect model and it is hypothesised that null hypothesis = random effect does not exist, alternative $=$ random effect exists. The result indicated in table 4 , that the $\mathrm{p}$ value is 0.000 and null hypothesis is rejected the in favour of the alternative which implied that random effect model is more appropriate than pooled OLS. In order to decide which one of the alternative 
panel analysis models whether it is fixed effect model or random effect model, Hausman specification test is performed. By performing the Hausman test statistics $(4.73, \mathrm{P}>0.05)$, it is identified that random effect model is appropriate as the null hypothesis accepted that random effects would be consistent and efficient. Therefore, random effect model is found to be most suitable to explain the impact of dividend policy on share price volatility in Sri Lankan non financial firms for the period from 2013 to 2017. Similar finding was observed by the Dewasiri and Weerakoon Banda (2014) and suggested that random effect model is suitable to examine the impact of dividend policy on share price volatility of non financial firm in Sri Lanka.

As per the random effect model presented in the table 4, $25 \%$ of the total variability in the share price volatility has been explained by dividend policy in Sri Lankan non financial firms for the period from 2013 to 2017. Out of five explanatory variables considered in this study, dividend per share $(\alpha=-0.0016, \mathrm{P}<0.01)$ and firm size $(\alpha=-0.0494, \mathrm{P}<0.01)$ have shown the significant negative impact on share price volatility. But, dividend yield $(\alpha=0.4406, \mathrm{P}<0.01)$ indicates significant positive impact on share price volatility. However, dividend payout $(\alpha=-0.0032, \mathrm{P}>$ $0.05)$ and firm leverage $(\alpha=0.0441, \mathrm{P}>0.05)$ have not shown any significant impact on share price volatility. Therefore, the results of the study are supported with $\mathrm{H}_{2}, \mathrm{H}_{3}$ and $\mathrm{H}_{4}$ that dividend yield, dividend per share and firm size have significant impact on share price volatility. But, findings of the study are not supported with $\mathrm{H}_{1}$ and $\mathrm{H}_{5}$ that dividend payout and leverage don't have any significant influence on share price volatility.

Result of the studies carried out by Sugathadasa (2018) and Mehmood (2019) are consistent with the finding of this study dividend payout doesn't have any impact on share price volatility. It contradicted with the findings of Hussainey et al., (2011), Hashemijoo et al., (2012), Dewasiri and Weerakoon Banda (2014), Alqudah and Yusuf (2015) and Nguyen et al., (2019) found the significant relationship between dividend payout and share price volatility. Dividend yield has significant positive influence on share price volatility in this study. Similar finding has been observed by previous study of Al-Shawawreh (2014). However, this result is contradicted with the studies of Ahmad et al., (2018) and Shah and Noreen (2016) found significant negative relationship between dividend yield and volatility of share price. Another contradicted study conducted by Gunarathne et al., (2016) in Sri Lanka revealed that there is no significant relationship between dividend yield and share price volatility.

Further, dividend per share has shown significant negative relationship with share price volatility in this study. This finding is also contradicted with the studies of Sulaiman (2015) and Dissanayake and Wickramasinghe (2016). According to the results, firm size has significant negative impact on share price volatility in the current study. This is validated with studies of Hashemijoo et al., (2012), Shah and Noreen (2016), Ali and Waheed (2017) and Hooi et al., (2015). But, contradicted with the studies of Al-Shawawreh (2014), Ahmad et al., (2018); Dewasiri and Weerakoon Banda (2014) and Nuwani (2015) as they have found the significant positive relationship. Finally, Leverage has not shown any significant relationship with share price volatility in this study. This outcome is contradicted with the results of Ahmad et al., (2018), Ali and Waheed (2017), Shah and Noreen (2016) and Zakaria et al., (2012) as they have found significant relationship. 


\section{CONCLUSION}

Purpose of the study is to examine the impact of dividend policy on share price volatility focusing 81 non financial firms listed on CSE for the period from 2013 to 2017. Panel data analysis is performed to test the impact and random effect model is identified as best model to explain in this empirical study. It was found that there is a significant positive relationship between dividend yield and share price volatility while dividend per share and firm size significantly negatively related to share price volatility. However, dividend payout and firm leverage have not shown any significant influence on share price volatility. In order to prevent their future investment, investor can make their decision to invest on the company shares which has lower risk of share price movement regarding dividend yield and dividend per share as they have significant impact on share price volatility. Outcome of the study is in line with the dividend relevant theory as there is a relationship between dividend policy and share price volatility. Policy makers and top management can identify the factors which are leading to the shareholders wealth relating to dividend policy of the firms. Further, it is suggested to future research which can be extended with all the sectors in the Colombo Stock Exchange and to other Asian region markets.

\section{REFERENCES}

Ahmad, M. A., Alrjoub, A. M. S. \& Alrabba, H. M. (2018). The Effect of Dividend Policy on Stock Price Volatility: Empirical Evidence from Amman Stock Exchange. Academy of Accounting and Financial Studies Journal, 22(2), 1-8.

Ali, T. \& Waheed, N. (2017). Impact of Dividend Policy on Share Price Volatility. Research Journal of Finance and Accounting, 8(9), 43-49.

AlQudah, A. \& Yusuf, A. (2015). Stock Price Volatility and Dividend Policy in Jordanian Firms. Research Journal of Finance and Accounting, 6(22), 149-159.

Al-Shawawreh, F. K. (2014). The Impact of Dividend Policy on Share Price Volatility: Empirical Evidence from Jordanian Stock Market. European Journal of Business and Management, 6(38), 133-143.

Asquith, P. \& David, W. M. (1983). The Impact of Initiating Dividend Payments on Shareholders' Wealth. Journal of Business, 56(1), 77-96.

Baker, H. K. \& Powell, G. E. (1999). How Corporate Managers View Dividend Policy? Quarterly Journal of Business and Economics, 38(2), 17-27.

Ball, R., Brown, P., Finn, F. J. \& Officer, R. R. (1979). Dividends and the Value of the Firm: Evidence from the Australian equity market. Australian Journal of Management, 4(1), 13-26.

Black, F. \& Scholes, M. S. (1974). The Effects of Dividend Yield and Dividend Policy on Common Stock Prices and Returns. Journal of Financial Economics, 1(1), 1-22.

Brennan, M. (1970). Taxes, Market Valuation and Financial Policy. National Tax Journal, 23(4), 417-427.

Dewasiri, N. J. \& Weerakoon Banda, Y. K. (2014). Impact of Dividend Policy on Stock Price Volatility: Evidence from Srilanka (pp. 15-20). Proceedings of 11th International Conference on Business Management.

Dissanayake, S. \& Wickramasinghe, M. (2016). Earnings Fluctuation on Share Price Volatility. Account and Financial Management Journal, 1(5), 360-368. 
Fama, E. F. \& French, K. R. (1988). Dividend Yields and Expected Stock Returns. Journal of Financial Economics, 22(1), 3 - 25.

Farrar, D. \& Selwyn, L. (1967). Taxes, Corporate Financial Policy and Return to Investors. National Tax Journal, 20(4), 444-454.

Gordon, M. J. (1963). Optimal Investment and Financing Policy. Journal of Finance, 18(2), 264272.

Gulet, S., Sajid, M., Razzaq, N., Iqbal, M. F. \& Khan, M. B. (2012). The Relationship Between Dividend Policy and Shareholder's Wealth. Economics and Finance Review, 2(2), 55 59.

Gunarathne, U. G. V. D. D., Priyadarshanie, W. A. N. \& Samarakoon, S. M. R. K. (2016). Impact of dividend policy on stock price volatility and market value of the firm: evidence from Sri Lankan manufacturing companies. Corporate Ownership and Control, 13(3), 219-225.

Hair, J. F., Tatham, R. L., \& Anderson, R. E. (1998). Multivariate Data Analysis. (5 $5^{\text {th }}$ ed.). New York: Prentice Hall.

Harshapriya, W. G. R. (2016). The Impact of Dividend Policy on Share Price Volatility: Evidence from Banking Stocks in Colombo Stock Exchange. Central Bank of Sri Lanka - Staff Studies, 46(1\&2), 27-67.

Hashemijoo, M., Ardekani, A. M., \& Younesi, N. (2012). The Impact of Dividend Policy on Share Price Volatility in the Malaysian Stock Market. Journal of Business Studies Quarterly, 4(1), 111-129.

Hooi, S. E., Albaity, M. \& Ibrahimy, A.I. (2015). Dividend Policy and Share Price Volatility. Investment Management and Financial Innovations, 12(1), 226-234.

Hussainey, K., Mgbame, C. O. \& Chijoke-Mgbame, A. M. (2011). Dividend Policy and Share Price Volatility: UK Evidence. Journal of Risk Finance, 12(1), 57-68.

Lashgari, Z., \& Ahmadi, M. (2014). The Impact of Dividend Policy on Stock Price Volatility in the Tehran Stock Exchange. Kuwait Chapter of the Arabian Journal of Business and Management Review, 3(10), 273-283.

Lintner, J. (1962). Dividends, Earnings, Leverage, Stock Prices and Supply of Capital to Corporations. The Review of Economics and Statistics, 44(3), 243-269.

Litzenberger, R. \& Ramaswamy, K. (1979). The Effect of Personal Taxes and Dividends on Capital Asset Prices: Theory And Empirical Evidence. Journal of Financial Economics, 7(2), 163-196.

Mgbame, C. O. \& Ikhatua, O. J. (2013). Accounting Information and Stock Volatility in the Nigerian Capital Market: A Garch Analysis Approach. International Review of Management and Business Research, 2(1), 265 - 281.

Miller, M. H. \& Modigliani, F. (1961). Dividend Policy, Growth, and the Valuation of Shares. The Journal of Business, 34(4), 411-433.

Mehmood, A. (2019). Determinants of Stock Price Volatility: Evidence from Cement Industry. Growing Science Ltd, 5(19), 145-152.

Nazir, M. S., Abdullah, \& Nawaz, M. M. (2011). How Dividend Policy Affects Volatility of Stock Prices of Financial Sector Firms of Pakistan. American Journal of Scientific Research, 61(61), 132-139.

Nguyen, D. T., Bui, M. H. \& Do, D. H. (2019). The Relationship of Dividend Policy and Share Price Volatility: A Case in Vietnam. Annals of Economics and Finance, 20(1), 123-136.

Nuwani, R. A. D. N. (2015). Impact of Corporate Dividend Policy on Share Price Volatility of Listed Companies in Colombo Stock Exchange. Proceedings of the 4th Students' 
Research Symposium, Department of Finance, Faculty of Commerce and Management Studies (pp. 26). University of Kelaniya, Sri Lanka.

Pratheepan, T., \& Yatiwella, K. W. B. (2016). The determinants of capital structure: Evidence from selected listed companies in Sri Lanka. International Journal of Economics and Finance, 8(2), 94-106.

Shah, S. A. \& Noreen, U. (2016). Stock Price Volatility and Role of Dividend Policy: Empirical Evidence from Pakistan. International Journal of Economics and Financial Issues, 6(2), 461-472.

Sugathadasa, D. D. K. (2018). The Impact of Dividend Policy on Share Price Volatility: Empirical Evidence with Colombo Stock Exchange in Sri Lanka. International Journal of Innovative Research \& Development, 7(8), 352-359.

Sulaiman, L. A. \& Migiro, S. O. (2015). Effect of Dividend Decision on Stock Price Changes: Further Nigerian Evidence. Investment Management and Financial Innovations, 12(1), 330-337.

Woolridge, J. R. (1983). Dividend Changes and Security Prices. The Journal of Finance, 38(5), 1607-1615.

Zainudin, R., Mahdzan, N. S., \& Yet, C. H. (2018). Dividend Policy and Stock Price Volatility of Industrial Products Firms in Malaysia. International Journal of Emerging Markets, 13(2), 203-217.

Zakaria, Z., Muhammad, J. \& Zulkifli, A. H. (2012). The Impact of Dividend Policy on the Share Price Volatility: Malaysian Construction and Material Companies. International Journal of Economics and Management Sciences, 2(5), 1-8. 